\title{
Corrigendum: Bacteriophage Procurement for Therapeutic Purposes
}

\author{
Beata Weber-Dąbrowska ${ }^{1,2 *}$, Ewa Jończyk-Matysiak ${ }^{1}$, Maciej Żaczek ${ }^{1}$, \\ Małgorzata B. Łobocka ${ }^{3,4}$, Marzanna Łusiak-Szelachowska ${ }^{1}$ and Andrzej Górski ${ }^{1,2,5}$ \\ ${ }^{1}$ Bacteriophage Laboratory, Ludwik Hirszfeld Institute of Immunology and Experimental Therapy, Polish Academy of \\ Sciences, Wroclaw, Poland, ${ }^{2}$ Phage Therapy Unit, Ludwik Hirszfeld Institute of Immunology and Experimental Therapy, Polish \\ Academy of Sciences, Wroclaw, Poland, ${ }^{3}$ Institute of Biochemistry and Biophysics, Polish Academy of Sciences, Warsaw, \\ Poland, ${ }^{4}$ Autonomous Department of Microbial Biology, Faculty of Agriculture and Biology, Warsaw University of Life \\ Sciences, Warsaw, Poland, ${ }^{5}$ Department of Clinical Immunology, Transplantation Institute, Medical University of Warsaw, \\ Warsaw, Poland
}

Keywords: bacteriophage isolation, therapeutic phages, experimental phage therapy, treatment of bacterial infections, antibiotic resistance

\section{A corrigendum on}

\section{OPEN ACCESS}

Edited and reviewed by: Peter Mullany,

University College London, UK

*Correspondence: Beata Weber-Dąbrowska weber@iitd.pan.wroc.pl

Specialty section:

This article was submitted to Antimicrobials, Resistance and Chemotherapy,

a section of the journal Frontiers in Microbiology

Received: 17 October 2016 Accepted: 28 October 2016 Published: 09 November 2016

Citation:

Weber-Dabrowska B, Jończyk-Matysiak E, Żaczek M, Łobocka MB, Łusiak-Szelachowska M and Górski A (2016) Corrigendum: Bacteriophage Procurement for Therapeutic Purposes.

Front. Microbiol. 7:1813. doi: 10.3389/fmicb.2016.01813

\section{Bacteriophage Procurement for Therapeutic Purposes}

by Weber-Dąbrowska, B., Jończyk-Matysiak, E., Żaczek, M., Łobocka, M. B., Łusiak-Szelachowska, M., and Górski, A. (2016). Front. Microbiol. 7:1177. doi: 10.3389/fmicb.2016.01177

In the original article, we neglected to include the Wrocław Centre of Biotechnology as a funding source. The full Funding statement should read as follows:

This work was financially supported by the project "Innovative Bacteriophage Preparation for the Treatment of Diabetic Foot" no. POIG.01.03.01-02-048/12 funded by the National Center for Research and Development. MŁ contribution was financially supported by the statutory funds for the Institute of Biochemistry and Biophysics, PAS. Publication was also supported by Wrocław Centre of Biotechnology, programme, the Leading National Research Centre (KNOW) for years 2014-2018.

The authors apologize for this oversight. This error does not change the scientific conclusions of the article in any way.

Conflict of Interest Statement: BW-D and AG are inventors of a patent (EP1 406642 B1, PL 19543781, US 7, 232564 B2) for procedure of preparing phages against S. aureus and P. aeruginosa (P382800; US 20100227376 A1) and a method of obtaining bacteriophage preparations containing trace amounts of endotoxins owned by the Institute of Immunology and Experimental Therapy. EJ-M, MŁ, MŻ, MŁ-S, declares that the research was conducted in the absence of any commercial or financial relationships that could be construed as a potential conflict of interest.

Copyright ( 2016 Weber-Dąbrowska, Jończyk-Matysiak, Żaczek, Łobocka, Łusiak-Szelachowska and Górski. This is an openaccess article distributed under the terms of the Creative Commons Attribution License (CC BY). The use, distribution or reproduction in other forums is permitted, provided the original author(s) or licensor are credited and that the original publication in this journal is cited, in accordance with accepted academic practice. No use, distribution or reproduction is permitted which does not comply with these terms. 